\title{
Changed Purine Nucleotide Concentrations and Enzyme Activities in Erythrocytes of Haemodialysis Patients Undergoing Erythropoietin Therapy
}

\author{
By W. Siems ${ }^{1}$, T. Grune ${ }^{1}$, Hannelore Hampl ${ }^{2}$, Gisela Wendel ${ }^{3}$, G. Gerber $^{1}$ and E. Riedel ${ }^{3}$ \\ 1 Institut für Biochemie, Charité, Humboldt-Universität zu Berlin \\ 2 Universitätsklinikum Rudolf Virchow, Freie Universität Berlin \\ 3 Institut für Biochemie, Freie Universität Berlin
}

(Received December 15, 1991/April 23, 1992)

\begin{abstract}
Summary: Therapy of renal anaemia in haemodialysis patients with chronic renal failure by application of recombinant human erythropoietin leads to an increase of the haematocrit. Rejuvenation of the erythrocyte population results in a decrease of the median density $\left(D_{50}\right)$, an increase of cell age-dependent enzyme activities, such as aspartate aminotransferase, and elevated concentrations of purine nucleotides in the erythrocytes. After density gradient separation of erythrocyte populations into cell age-dependent fractions, the concentrations of adenosine-5'-triphosphate, guanosine-5'-triphosphate and guanosine-5'-diphosphate were be found to be elevated by $25-100 \%$ in all cell fractions from haemodialysis patients, compared with a healthy control group. Therapy of haemodialysis patients with recombinant human erythropoietin leads to further increase $(65 \%)$ of ATP in the younger (low density) cells, but not in the older (high density) cells. The elevated concentrations of ATP and total adenine nucleotides during recombinant human erythropoietin therapy possibly result in improved deformability of erythrocytes. The data point to an enhancement of the proportion of younger erythrocytes, but not to an improvement of the reduced life span of erythrocytes of haemodialysis patients during therapy with recombinant human erythropoietin.
\end{abstract}

\section{Introduction}

Anaemia in patients with chronic renal failure (renal anaemia) is partly caused by a reduction of erythropoietin synthesis. This results in diminished production of erythrocytes in these patients. Additionally, the life span of erythrocytes of uraemic patients is reduced $(1-4)$. The life span of erythrocytes is determined by their energy metabolism, which is given by the flux rate through glycolysis and ATP production via this pathway (5). One cause of a decreased life

\footnotetext{
1) Enzymes

Aspartate aminotransferase (EC 2.6.1.1)

Hexokinase (EC 2.7.1.1)

Aldolase (EC 4.1.2.13)

Pyruvate kinase (EC 2.7.1.40)

Glucose-6-phosphate dehydrogenase (EC 1.1.1.49)
}

span of erythrocytes of uraemic patients may be an increased activity of plasma neuraminidase (6). Furthermore, there are several reports of oxygen damage of erythrocytes in uraemic patients due to an imbalance between prooxidative reactions and antioxidative defence mechanisms (7).

For the past few years it has been possible to treat renal anaemia by administration of recombinant human erythropoietin (1). The enhancement of haematocrit during recombinant human erythropoietin therapy due to stimulation of erythropoiesis in these patients leads to an improved oxygen supply and, therefore, to an improvement of the conditions required for many metabolic functions. Data on the improvement of protein metabolism during recombinant human erythropoietin therapy have already been re- 
ported (8). Stimulation of erythrocyte formation during recombinant human erythropoietin administration is accompanied by a significant decrease in the proportion of median density $\left(\mathrm{D}_{50}\right)$ of erythrocytes, and by increased cell age-dependent enzyme ${ }^{1}$ ) activities in all erythrocyte fractions $(9-11)$.

The aim of this study was to answer the following questions.

1) Can the increased deformability of erythrocytes following recombinant human erythropoietin therapy, as measured in rheological studies $(12,13)$, be interpreted on the basis of elevated intraerythrocytic energy-rich purine nucleotides?

2) Is recombinant human erythropoietin therapy of haemodialysis patients accompanied by an increase in the life span of erythrocytes, based on purine nucleotide measurements?

3) Do the erythrocytes of haemodialysis patients exhibit changes in purine nucleotide pattern during long term (1 year) therapy with recombinant human erythropoietin?

\section{Patients and Methods}

Eighteen healthy subjects ( 8 male and 10 female subjects), aged from 21 to 56 years, were compared as a control group with 14 haemodialysis patients ( 4 male and 10 female patients) aged from 26 to 76 years $[\mathrm{Hb} 81.5 \pm 5.1 \mathrm{~g} / 1]$. The uraemic patients were haemodialysed three times per week for $4-5$ hours. The recombinant human erythropoietin dosage was chosen to produce an enhancement of haemoglobin concentrations up to 100 $\mathrm{g} / \mathrm{l}$, followed by maintenance of this value. Recombinant human erythropoietin was a gift of Boehringer Mannheim $\mathrm{GmbH}$, Germany.

Blood samples (3-5 ml venous blood) from haemodialysis patients were drawn in the morning before haemodialysis sessions. Informed consent was obtained according to standards of the Ethic Committee of the Department of Medicine of the Freie Universität Berlin. Blood samples from control subjects were also drawn in the morning. Preparations for the different assays were immediately carried out.

Erythrocyte suspensions for density gradient centrifugation were prepared from heparinized blood. Blood $(10 \mathrm{ml})$ was centrifuged for $10 \mathrm{~min}$ at $4{ }^{\circ} \mathrm{C}$ and $800 \mathrm{~g}$. Plasma was removed and erythrocytes were resuspended in N-2-hydroxyethylpiperazine$\mathrm{N}^{\prime}$-2-ethanesulphonic acid (HEPES) buffer $(133 \mathrm{mmol} / \mathrm{l} \mathrm{NaCl}$, $4.5 \mathrm{mmol} / \mathrm{l} \mathrm{KCl}, 10 \mathrm{mmol} / \mathrm{l} \mathrm{HEPES}, \mathrm{pH} 7.4)$. The suspension was filtered through $\alpha$-cellulose/microcrystalline cellulose $(2+1$, by weight) according to Beutler et al. (14) to eliminate leukocytes. The haematocrit of filtered blood was adjusted to about 0.30 with HEPES buffer $\left(4^{\circ} \mathrm{C}\right)$.

Percoll gradient separation (11): $2 \mathrm{ml}$ of filtered blood were layered on top of $12 \mathrm{ml}$ of a continuous Percoll density gradient solution and centrifuged for $10 \mathrm{~min}$ at $10000 \mathrm{~g}$ in a Sorvall centrifuge at $4{ }^{\circ} \mathrm{C}$. The density gradient was obtained by centrifugation of a $50 \%$ Percoll solution in HEPES buffer for 10 min at $10000 \mathrm{~g}$ and $4{ }^{\circ} \mathrm{C}$. Separated erythrocytes were collected from the bottom of the vials in 24 fractions $(500 \mu l)$ using a pump and a glass capillary. Fraction 1, the highest density fraction, was located at the bottom; fraction 24 , the lowest density fraction, was located at top of the vial. Densities of the fractions were determined with the help of colour markers. Each fraction was washed three times with $1000 \mu \mathrm{l}$ HEPES buffer. Centrifugation was carried out in Eppendorf vials and an Eppendorf centrifuge. Erythrocyte pellets were kept deep frozen at $-20^{\circ} \mathrm{C}$ until determination of enzyme activities. Samples for purine nucleotide analysis were immediately extracted.

Extraction procedure of nucleotides: Fractions were deproteinized with ice cold $60 \mathrm{~g} / \mathrm{l}$ perchloric acid, centrifuged for $10 \mathrm{~min}$ at $1200 \mathrm{~g}$ and neutralized with $\mathrm{K}_{2} \mathrm{CO}_{3}$. After a second centrifugation the supernatant was stored at $-20^{\circ} \mathrm{C}$. Ten or twenty microlitres of supernatant were analysed by $\operatorname{HPLC}(15,16)$. HPLC equipment of Waters Assoc., Milford, MA; USA: M510 pump, Rheodyne injector, variable wavelength detector (adjusted to $254 \mathrm{~nm}$ ), 740 DATA Module and a 640-system controller; columns: $5 \mu \mathrm{m}$ Novapak $\mathrm{C}_{18}$ cartridges $(100 \mathrm{~mm}$ $\times 8 \mathrm{~mm}$ i.d.) with a RCM compression system. Purine nucleotides were determined with an isocratic ion pair reversed phase HPLC system $(15,16)$. The eluent contained $10 \mathrm{mmol} / \mathrm{l}$ $\mathrm{NH}_{4} \mathrm{H}_{2} \mathrm{PO}_{4}, 2 \mathrm{mmol} / \mathrm{PIC}$ reagent $\mathrm{A}$ and acetonitrile, volume fraction 0.2 . Flow rate: $2 \mathrm{ml} / \mathrm{min}$.

Activities of aspartate aminotransferrase ${ }^{1}$ ) were determined after thawing and suspending erythrocyte pellets in $300 \mu$ l aqua bidest using the GOT test kit No. 3329 (Merck Darmstadt, Germany). Haemoglobin concentration was measured with the Merckotest kit No. 3317 (Merck Darmstadt, Germany).

\section{Results}

Erythrocytes from patients with chronic renal failure undergoing haemodialysis exhibit increased enzyme activities in all cell fractions of the Percoll gradient in comparison with erythrocytes from healthy subjects. The most prominent differences between enzyme activities of patients and healthy subjects were found in cell fractions $15-24$, which contain erythrocytes with low densities. These erythrocytes were termed young erythrocytes, as indicated by the cell age-dependent aspartate aminotransferase activity (17) (fig. 1). During recombinant human erythropoietin therapy, catalytic activity concentrations of aspartate aminotransferase increase, reaching a maximum one week after the start of therapy. However, these activities decrease to the initial value during the first year of therapy.

In contrast to restoration of enzyme activity after the first year of recombinant human erythropoietin therapy, median densities stay constantly low, demonstrating a continuous generation of young erythrocytes during the time of recombinant human erythropoietin administration: haemodialysis patients $\mathrm{D}_{50}=1.0548 \pm 0.0002 \mathrm{~kg} / 1\left(\mathrm{p}_{\text {control }}<0.05\right)$; haemodialysis patients after one year of recombinant human erythropoietin therapy $\mathrm{D}_{50}=1.0543 \pm 0.0009 \mathrm{~kg} / \mathrm{l}$, $\left(\mathrm{p}_{\text {control }}<0.05\right)$; healthy control group $\mathrm{D}_{50}=1.0740$ $\pm 0.0002 \mathrm{~kg} / \mathrm{l}$. Like the aspartate aminotransferase activities, the ATP concentrations in erythrocytes of haemodialysis patients are increased in comparison 


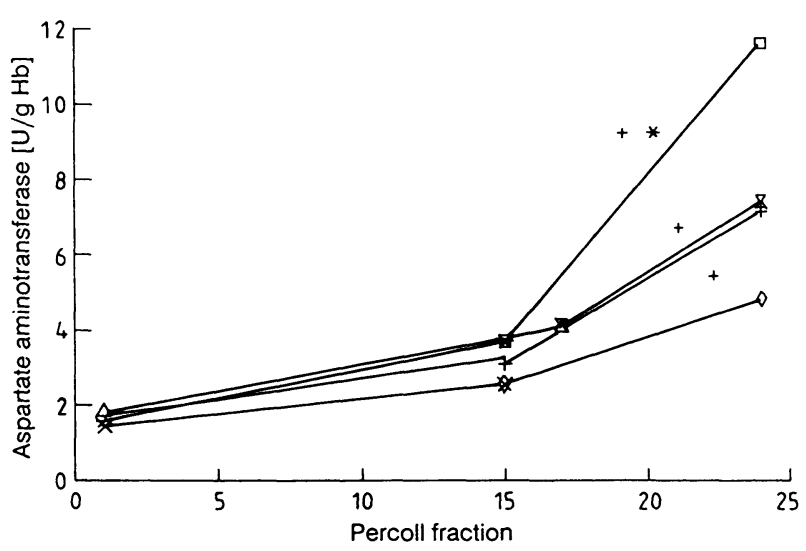

Fig. 1. Aspartate aminotransferase activities in erythrocyte fractions of Percoll density gradient. High density fractions $1-15$ are old cell fractions, low density fractions 15-24 are young cell fractions. Comparison of haemodialysis patients before $(+)$, during 1 week $(\square)$ and during 1 year $(\nabla)$ of recombinant human erythropoietin therapy with values of a healthy control group $(\diamond)$. Significance (Student's t):

* $\mathrm{p}$ (before therapy) $<0.05$

$+\mathrm{p}$ (control) $<0.05$

with healthy subjects (tab. 1). Furthermore, the ATP content in young erythrocyte fractions is significantly higher during recombinant human erythropoietin treatment than before recombinant human erythropoietin administration. The ATP content of the "old" cells (fractions 1-15) after the first year of recombinant human erythropoietin therapy shows no differences compared with the value before the start of therapy. On the other hand, concentrations of ADP in old fractions and AMP in young and old erythrocyte fractions of recombinant human erythropoietin treated patients show significantly higher values than those of the patients before recombinant human erythropoietin therapy (tab. 1). GTP and GDP concentrations are increased in erythrocytes of haemodialysis patients compared with a healthy control group (fig. 2), but show no significant changes between haemodialysis patients before and after recombinant human erythropoietin therapy (tab. 1).

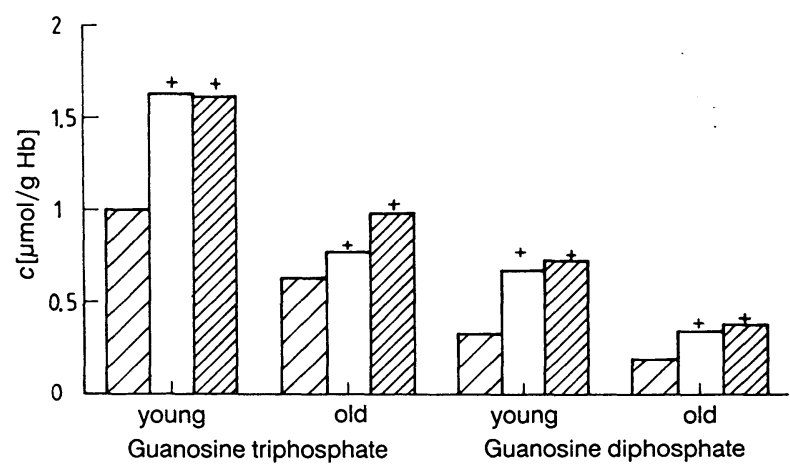

Fig. 2. Guanosine nucleotide content in erythrocytes (young and old cell fractions) of haemodialysis patients before ( $\square$ ) and after one year of therapy with recombinant human erythropoietin $(\mathbb{Z})$ compared with a healthy control group ( $\square)$.

Significance (Student's t):

$+\mathrm{p}$ (control) $<0.05$.

\section{Discussion}

Cell densities of erythrocytes increase with increasing cell age for nearly 120 days, the physiological life span of human erythrocytes. Therefore, the median density of the erythrocyte population has been suggested as an indicator for changes of cell age (14). Thus, the

Tab. 1. Purine nucleotide concentrations in erythrocytes of haemodialysis (HD) patients before and after one year of recombinant human erythropoietin (rhEPO) therapy compared with a healthy control group.

Significance (Student t-test): $+\mathrm{p}_{(\text {control })}<0.05,+<0.01 ;{ }^{*} \mathrm{p}_{(\mathrm{HD} / \mathrm{rhEPO})}<0.05, * *<0.01$.

\begin{tabular}{|c|c|c|c|c|}
\hline & $\begin{array}{l}\text { Cell } \\
\text { fraction }\end{array}$ & $\begin{array}{l}\text { Control group } \\
\mu \mathrm{mol} / \mathrm{g} \mathrm{Hb}\end{array}$ & $\begin{array}{l}\text { Haemodialysis patients } \\
\mu \mathrm{mol} / \mathrm{g} \mathrm{Hb}\end{array}$ & $\begin{array}{l}\text { Recombinant human erythro- } \\
\text { poietin treated patients } \\
\mu \mathrm{mol} / \mathrm{g} \mathrm{Hb}\end{array}$ \\
\hline ATP & $\begin{array}{l}\text { young } \\
\text { old } \\
\mathrm{p}_{(\mathrm{y} / \mathrm{o})}<\end{array}$ & $\begin{array}{l}3.47 \pm 1.59 \\
2.18 \pm 0.42 \\
0.05\end{array}$ & $\begin{array}{l}4.38 \pm 1.34+ \\
4.02 \pm 1.71++ \\
0.05\end{array}$ & $\begin{array}{l}7.29 \pm 2.68++* * \\
3.82 \pm 1.75+ \\
0.01\end{array}$ \\
\hline ADP & $\begin{array}{l}\text { young } \\
\text { old } \\
\mathrm{p}_{(\mathrm{y} / \mathrm{o})}<\end{array}$ & $\begin{array}{l}2.23 \pm 0.93 \\
0.79 \pm 0.26 \\
0.01\end{array}$ & $\begin{array}{l}2.23 \pm 0.63 \\
1.52 \pm 0.46++ \\
0.05\end{array}$ & $\begin{array}{l}2.26 \pm 0.49 \\
1.87 \pm 0.51+^{*} \\
0.05\end{array}$ \\
\hline AMP & $\begin{array}{l}\text { young } \\
\text { old } \\
\mathrm{p}_{(\mathrm{y} / \mathrm{o})}<\end{array}$ & $\begin{array}{l}0.72 \pm 0.27 \\
0.28 \pm 0.06 \\
0.05\end{array}$ & $\begin{array}{l}0.72 \pm 0.24 \\
0.32 \pm 0.09 \\
0.05\end{array}$ & $\begin{array}{l}1.16 \pm 0.31++^{* *} \\
0.52 \pm 0.20+^{*} \\
0.01\end{array}$ \\
\hline GTP & $\begin{array}{l}\text { young } \\
\text { old } \\
\mathrm{p}_{(\mathrm{y} / \mathrm{o})}<\end{array}$ & $\begin{array}{l}1.00 \pm 0.65 \\
0.63 \pm 0.08 \\
0.05\end{array}$ & $\begin{array}{l}1.63 \pm 0.50+ \\
0.77 \pm 0.32+ \\
0.05\end{array}$ & $\begin{array}{l}1.61 \pm 0.61+ \\
0.98 \pm 0.54+ \\
0.01\end{array}$ \\
\hline GDP & $\begin{array}{l}\text { young } \\
\text { old } \\
\mathrm{p}_{(\mathrm{y} / \mathrm{o})}<\end{array}$ & $\begin{array}{l}0.33 \pm 0.19 \\
0.19 \pm 0.05 \\
0.05\end{array}$ & $\begin{array}{l}0.67 \pm 0.16++ \\
0.34 \pm 0.60++ \\
0.005\end{array}$ & $\begin{array}{l}0.72 \pm 0.31++ \\
0.38 \pm 0.20++ \\
0.01\end{array}$ \\
\hline
\end{tabular}


decrease of median density $\left(D_{50}\right)$ of erythrocytes in patients with chronic renal failure, undergoing haemodialysis and treatment with recombinant human erythropoietin can be interpreted on the basis of an accelerated generation of young erythrocytes $(9-11)$. The activities of many enzymes of erythrocytes are cell age-dependent. In particular, the activities of hexokinase, aldolase, pyruvate kinase and aspartate aminotransferase decrease during cell aging $(18,19)$. Aspartate aminotransferase in this study and in earlier studies of our group served as a marker enzyme for the age of erythrocytes. Erythrocyte density fractions of haemodialysis patients showed significantly higher aspartate aminotransferase activities (11) as an expression of reduced life span, which was demonstrated by means of ${ }^{51} \mathrm{Cr}$ experiments (3). In addition to an elevated aspartate aminotransferase ${ }^{1}$ ) activitiy, erythrocytes of haemodialysis patients also exhibit elevated pyruvate kinase ${ }^{1}$ ), hexokinase ${ }^{1}$ ) and glucose6-phosphate dehydrogenase ${ }^{1}$ ) activities (20).

After the first year of administration of recombinant human erythropoietin to patients, the enzyme activity decreases rapidly to values found in the cell population of patients without recombinant human erythropoietin therapy; this indicates that the toxic damage of the erythrocytes due to uraemia, persists during recombinant human erythropoietin therapy.

We found increased ATP and GTP concentrations in erythrocytes of haemodialysis patients. The increased erythrocytic ATP concentrations in uraemic patients are in agreement with previously published data (21 24). To our knowledge, the observation of elevated GTP concentrations, however, is a new finding. Increased ATP concentrations in uraemic erythrocytes may be due, on the one hand to a decreased loss of ATP during ageing of erythrocytes (25) and, on the other hand to changes in enzyme activities in pathways of nucleotide metabolism. Generally speaking, increases or decreases of ATP concentrations of erythrocytes reflect differences between production and consumption of this energy rich compound. In erythrocytes, generation of ATP only depends upon the flux rate through glycolysis, regulated by the enzyme activities of this pathway, especially by the activity of the key enzymes, hexokinase and phosphofructokinase. Hexokinase activity in erythrocytes is strongly cell age-dependent $(17,26)$. This might be the reason for the decreased ATP concentrations in erythrocytes in dependence upon density in all three groups of patients or healthy subjects. On the other hand, the ATP consuming processes, especially transport processes through plasma membranes and processes connected with cell shape changes mediated by cytoske- leton activities, influence the topical ATP level. From a comparison between immature red blood cells the reticulocytes - and mature red blood cells - the erythrocytes - is known that reticulocytes exhibit a 75-fold higher rate of ATP consumption (27) and a 3-fold higher ATP concentration (28) in comparison with erythrocytes. Therefore, one may suggest that "old" erythrocytes with lower ATP content are probably characterized by a decreased ATP consumption rate under quasi steady state conditions when compared with younger cells. This may be in agreement with the disturbances of electrolyte concentrations in red cells with ageing, especially with the decrease of intracellular $\mathrm{K}^{+}$and $\mathrm{Mg}^{2+}$ and an increase of intracellular $\mathrm{Na}^{+}$concentration (29).

Increased ATP concentrations in erythrocytes of uraemic patients seem to be connected with decreased cell age; in addition, they are possibly associated with the adaptation of cells to the higher demand for the transport of electrolytes and organic compounds which are accumulated in the plasma. Furthermore, changes of enzyme activities in pathways of nucleotide metabolism in the erythrocytes of haemodialysis patients have been described by Hefti et al. (3), who showed an enhanced purine nucleotide synthesis via salvage pathways in erythrocytes of uraemic patients. The possible influence of higher phosphate concentrations on the erythrocyte glycolytic rate has also been discussed $(20,20,31)$.

The increase of the ATP concentration after the long term presence of erythropoietin can be explained as rejuvenation of the erythrocyte population. There is no doubt that in the presence of recombinant human erythropoietin the life span of red cells in haemodialysis patients remains the same (or slightly increased), compared with cells in haemodialysis patients before recombinant human erythropoietin treatment. Nevertheless, the causes of ATP enhancement in erythrocytes during recombinant human erythropoietin treatment are unknown. Tracer-kinetic experiments are necessary to obtain more information on the balance between ATP formation and consumption in erythrocytes in haemodialysis patients treated with recombinant human erythropoietin. This might answer the question of which part of ATP turnover is changed during the recombinant human erythropoietin treatment - the ATP production via glycolysis or the ATP consuming processes.

The increased ATP concentration together with increased aspartate aminotransferase activities in "old" erythrocytes from haemodialysis patients treated with recombinant human erythropoietin, compared with "old" erythrocytes before recombinant human eryth- 
ropoietin therapy (fig. 1) may indicate an unchanged reduced life span of erythrocytes during recombinant human erythropoietin therapy. This finding is in agreement with data published in 1.c. (12). These authors measured an unchanged reduced life span of erythrocytes before and 6 months after recombinant human erythropoietin therapy.

The increased nucleotide concentrations of erythrocytes of haemodialysis patients treated with recombinant human erythropoietin can explain the partial restoration of the decreased erythrocyte deformability in haemodialysis patients $(12,13)$. Several authors have clearly demonstrated the decrease of deformability of erythrocytes in patients with chronic renal failure (32). The reasons for the beneficial recombinant human erythropoietin effect on the rheological properties of the blood $(12,13)$ are not yet clarified. The improved deformability of uraemic erythrocytes by the recombinant human erythropoietin therapy was explained by the assumption that during recombinant human erythropoietin therapy an increasing number of cells with normalized viscoelastic properties was formed due to stimulated erythropoiesis (13). It is well known that the biochemical and biophysical state of the cytoskeleton, which is attached to the cytoplasmatic membrane surface, is of direct importance for the viscoelastic properties of the cell membrane, and therefore determines the deformability of the whole erythrocyte. It was mentioned above that several authors have related the reduced deformability of uraemic erythrocytes to a permanent oxidative stress caused by so called uraemic toxins in the blood plasma (7). If the impaired deformability is primarily caused by the action of uraemic toxins, one would expect that the erythrocytes formed under the recombinant human erythropoietin therapy would also possess this feature. But the findings of Meier et al. (13) underline the fact that the impaired deformability of erythrocytes from haemodialysed patients cannot be attributed alone to an action of "uraemic toxins" during ageing of erythrocytes in the blood circulation. On the basis of the results presented here we propose that the further increase of the intraerythrocytic concentrations of energy-rich adenosine nucleotides, especially ATP and AMP, within the younger cell fractions, and ADP and AMP in the older cell fractions, during recombinant human erythropoietin therapy, is responsible for the improvement of rheological properties of the blood of patients with chronic renal failure. Thus, the results of our study point to an increase of haemocrit with an enhancement of the proportion of younger erythrocytes, but not to an improvement of the reduced life span of erythrocytes of haemodialysis patients during recombinant human erythropoietin therapy.

\section{Acknowledgement}

The authors gratefully appreciate the helpful support of Dr. $P$. Scigalla (Fa. Boehringer/Mannheim), and are grateful to Mrs. Manuela Jakstadt for her excellent technical assistance.

\section{References}

1. Eschbach, I. W. \& Adamson, I. W. (1985) Anemia of endstage renal disease. Kidney Int. 28, 1-5.

2. Fisher, J. W. (1980) Mechanism of anemia of chronic renal failure. Nephron 25, 106-111.

3. Hefti, J. E., Blumberg, A. \& Marti, H. R. (1983) Red cell survival and red cell enzymes in patients on continuous peritoneal dialysis (CAPD). Clin. Nephrol. 19, 232-235.

4. Massry, S. G. \& Goldstein, D. A. (1978) Role of parathyroid hormone on uremic toxicity. Kidney Int. Supp. 8, $39-42$.

5. Clark, M. R., Mohandas, N., Feo, C. \& Jacobs, M. S. (1981) Separate mechanisms of deformability loss in ATP depleted and $\mathrm{Ca}$ loaded erythrocytes. J. Clin. Invest. 67, $531-539$.

6. Gafter, U., Levinsky, H., Malachi, T., Levi, J., Bogin, E. \& Allalouf, D. (1985) Sialic acid content of erythrocytes in uremic patients. Nephron 40, 463-466.

7. Rosenmund, A., Binswanger, U. \& Straub, P. (1975) Oxidative injury to erythrocytes, cell rigidity and splenic hemolysis in hemodialyzed uremic patients. Ann. Intern. Med. $82,460-465$.

8. Riedel, E., Hampl, H., Scigalla, P., Nündel, M. \& Kessel, M. (1989) Correction of amino acid metabolism by recombinant human erythropoietin therapy in hemodialysis patients. Kidney Int. 36, 216-221.

9. Hampl, H., Riedel, E., Wendel, G., Neuymayr, H., Nispel, K. \& Scigalla, P. (1990) Veränderung der Erythrocyteneigenschaften bei Hämodialysepatienten im Verlauf der Therapie mit rekombinantem Erythropoietin. Nieren- und Hochdruckkrankheiten 19, 205-210.

10. Hampl, H., Riedel, E., Wendel, G. \& Scigalla, P. (1990) Red blood cell density distribution in uremic patients on acetate and bicarbonate hemodialysis. Blood Purif. 8, 260267.

11. Hampl, H., Riedel, E., Scigalla, P., Stabell, U. \& Wendel, G. (1990) Erythropoiesis and erythrocyte age distribution in hemodialysis patients undergoing erythropoietin therapy. Blood Purif. 8, 117-125.

12. Schmidt, R., Lerche, D., Dörp, E. \& Klinkmann, H. (1991) Changes in red blood cell function under rhEPO treatment. 10. Donausymposium of Nephrology, Budapest.

13. Meier, W., Paulitschke, M., Lerche, D., Schmidt, G. \& Zoellner, K. (1991) Action of rHuEpo on mechanical membrane properties of red blood cells in children with endstage renal disease. Nephrol. Dial. Transplant. 6, 110-116.

14. Beutler, E., West, C. \& Blume, K.-G. (1976) The removal of leukocytes and platelets from whole blood. J. Lab. Clin. Med. 88, 328-333.

15. Werner, A., Grune, T., Siems, W., Schneider, W., Shimasaki, H., Esterbauer, H. \& Gerber, G. (1989) Nucleotide and aldehyde analysis by HPLC for determination of radical induced damage. Chromatographia 28, 65-68. 
16. Werner, A., Schneider, W., Siems, W., Grune, T. \& Schreiter, C. (1989) Ionpair reversed phase HPLC determination of nucleotides, nucleosides and nucleobases. Chromatographia $27,639-643$.

17. Lindena, J., Wittenberg, H., Diederichs, F. \& Trautschold, I. (1989) The decline of catalytic enzyme activity concentration of in vivo ageing erythrocytes of the man, the dog and the rat. J. Clin. Chem. Clin. Biochem. 24, 49-59.

18. Seaman, C., Wyss, S. \& Piomelli, S. (1980) The decline in energetic metabolism with aging of the erythrocyte and its relationship to cell death. Ann. J. Hematol. 8, 31-42.

19. Turner, B. M., Fisher, R. A. \& Harris, H. (1974) The agerelated loss of activity of four enzymes in the human erythrocyte. Clin. Chim. Acta 50, 85.

20. Wallas, Ch. H. (1974) Metabolic studies on red cells from patients with chronic renal disease on hemodialysis. Br. J. Haematol. 26, $71-78$.

21. Monti, J. P., Gallice, P., Baas, M., Murisasco, A. \& Crevat, A. (1987) Modification of intraerythrocytic homeostasis in uremic patients, as studied with $31 \mathrm{P}$ nuclear magnetic resonance. Clin. Chem. 33, 76-80.

22. Jablonska-Skwiecinska, E., Staniszewska, K. \& Kowalska, H. (1987) The red cell sodium, potassium, inorganic phosphate, ATP and 2,3DPG concentrations in chronic renal failure. Folia Haematol. 114, 493-495.

23. Kuroynagi, T., Kurisu, A., Sugiyama, H. \& Saito, M. (1964) The ADP and ATP levels and the phosphorylating activity of erythrocytes in patients with uremia associated with chronic renal failure. Tokohu J. Exp. Med. 84, 105.

24. Lichtman, M. A., Miller, D. R. \& Freeman, R. B. (1969) Erythrocyte adenosine triphosphate depletion during hypophosphatemia in a uremic subject. New Engl. J. Med. $280,240$.
25. Bartosz, G., Grzelinska, E. \& Wagner, J. (1982) Aging of the erythrocyte. XIV. ATP content does decrease. Experientia 38,575 .

26. Chapman, R. G. \& Schaumburg, L. (1967) Glycolysis and glycolytic enzyme activity of aging red cells in man. Br. J. Haematol. 13, 665-678.

27. Siems, W., Dubiel, W., Dumdey, R., Müller, M. \& Rapoport, S. M. (1984) Accounting for the ATP consuming processes in rabbit reticulocytes. Eur. J. Biochem. 139, $101-107$.

28. Werner, A., Siems, W. \& Gerber, G. (1988) Purine and pyrimidine nucleotides in rabbit red blood cells of different maturity. Cell Biochem. Function 6, 251-256.

29. Bartosz, G., Swierczynska, B. \& Gondko, R. (1980) Aging of the erythrocyte. III. Cation content. Experientia 37 $723-724$

30. Becher, H. J., Weise, H. J., Volkermann, U. \& Schollmeyer, P. (1980) Enhanced purine nucleotide synthesis in erythrocytes of uremic patients. Klin. Wochenschr. 58, 12431250.

31. Lichtman, M. A. \& Miller, D. R. (1970) Erythrocyte glycolysis, 2,3-diphosphoglycerate and adenosine triphosphate concentration in uremic subjects: relationship to extracellular phosphate concentration. J. Lab. Clin. Med. 76, 267279.

32. Udden, M. M., O'Rear, E. A. \& Kegel, H. (1984) Decreased deformability of erythrocytes and increased intracellular calcium in patients with chronic renal failure. Clin. Hemorheology $4 / 5,473-481$.

Prof. Dr. Eberhard Riedel

Institut für Biochemie der Freien Universität Berlin

Limonenstraße 7

D-1000 Berlin 45

Bundesrepublik Deutschland 